\title{
Paucisymptomatic clinical presentation of an advanced malignant lung disease: solitary skull metastasis as the initial exploratory sign
}

\author{
Rafael García Carretero (D) ,' Maria Ordonez-Garcia, ${ }^{2}$ Sonia Hernandez-Puche, ${ }^{1}$ \\ Paloma Arias-Baldo ${ }^{3}$
}

${ }^{1}$ Internal Medicine, Hospital Universitario de Mostoles, Mostoles, Madrid, Spain ${ }^{2}$ Hematology, Hospital Universitario de Mostoles, Mostoles, Madrid, Spain ${ }^{3}$ Radiology, Hospital Universitario de Mostoles, Mostoles, Madrid, Spain

Correspondence to Dr Rafael García Carretero; rgcarretero@salud.madrid.org

Accepted 30 January 2022

\section{DESCRIPTION}

A 64-year-old female smoker was admitted to our hospital with increasing pain in the right shoulder for the prior 4-6 weeks. She also presented with a dry, non-productive cough. She denied any further symptoms, and she had no fever, weight loss or fatigue. Because of the cough, she had visited her general practitioner, who asked for a chest X-ray, which revealed a large mass in the lower lobe of the right lung, probably with right lymphadenopathies (figure 1A). The results of laboratory blood tests were normal, including white and red blood cell counts, as well as liver, lipid and kidney panels. Her primary care physician referred her to our hospital.

Physical examination revealed no diplopia, anisocoria or ptosis but we identified a painless, solitary scalp lump (3-4 cm in diameter) that had remained unnoticed by the patient. It was not noticed by her relatives either.

Thoracic CT scan revealed a large mass in the right lobe, with multiple bilateral, mediastinal and hilar lymph node enlargements and right pulmonary vein thrombosis (figure 1B). A cranial CT scan was performed to characterise the scalp lump. It showed a solitary osteolytic lesion on the right parietal bone $(4.5 \mathrm{~cm})$, with bony erosion, suggesting aggressiveness; it was considered a metastasis of an unknown primary tumour (figure 2). Figure 3 shows slides of a positron emission tomography-CT scan. It showed abnormalities in the right lobe and multiple bilateral, mediastinal and hilar lymph malignant nodes with a maximum standardised uptake value of 14.87 (levels higher than 2.5 can be considered abnormal).

The patient underwent a bronchoscopy, which revealed incomplete obstruction of the right main bronchus and complete obstruction of the right middle lobe bronchus. A biopsy was obtained, which
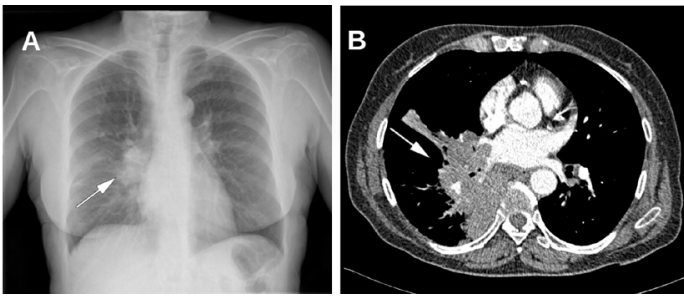

Figure 1 (A) A right pulmonary hilar tumour mass in a plain X-ray. (B) Thoracic CT scan showing a large mass with mediastinal and hilar lymph node enlargements.

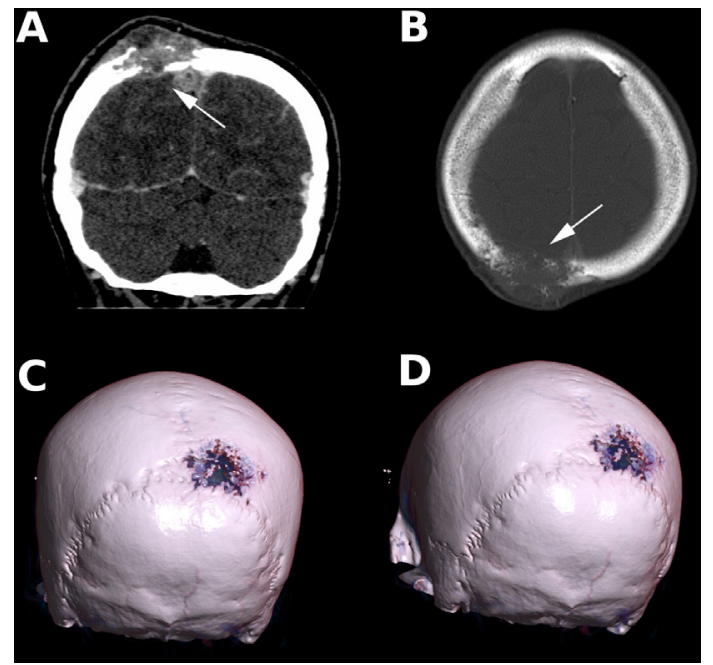

Figure $2(A, B)$ A lytic lesion in the parietal bone of the skull. $(C, D) A$ BD reconstruction.

revealed non-small-cell lung cancer. Immunochemistry staining was positive for thyroid transcription factor- 1 and negative for $\mathrm{p} 63$, which confirmed the histopathological diagnosis.

Further investigation revealed bone and liver involvement (metastases to parietal bone, thoracic and lumbar vertebrae and scapular bone). The patient underwent chemotherapy treatment with carboplatin-pemetrexed. The patient was also referred to radiotherapy oncologists for radiotherapeutic treatment (five cycles of $400 \mathrm{cGy}$ ), but it was suspended because her clinical condition rapidly worsened. The patient passed away 4 months after the diagnosis.

It is worth noting that echinoderm microtubuleassociated protein-like 4 (EML4)-anaplastic

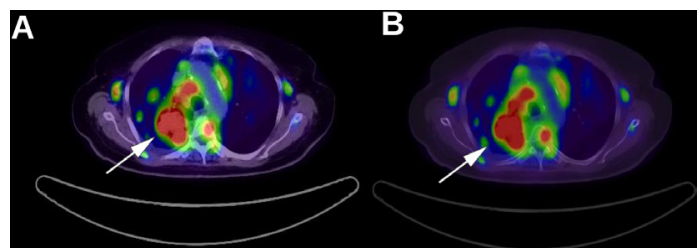

Figure $3(\mathrm{~A}, \mathrm{~B})$ Intense 18F-labelled 2-fluoro-2deoxyglucose uptake in the right lobe and several bilateral, mediastinal and hilar lymph pathological nodes, when the patient underwent a positron emission tomography-CT scan. 
lymphoma kinase (ALK)-positive lung cancer is associated with lung adenocarcinoma, the main differential diagnosis proposed by our pathologist. Likewise, epidermal growth factor receptor (EGFR)-positive cells are associated with non-small-cell lung cancer. Unfortunately, these immunochemistry techniques were not available at our pathology laboratory at the time of the diagnosis of our patient (2016). This is an interesting aspect of the case because our patient underwent a carboplatin-pemetrexed regime, instead of taking EML4-ALK-positive or EGFR-positive lung-tumor-specific drugs, such as crizotinib, ceritinib, afatinib or erlotinib.

Primary tumours of the skull are uncommon, but up to $80 \%$ of secondary bone scalp tumours are malignant ${ }^{1}$ and their differential diagnosis can be broad (cysts, fibrous dysplasia, osteomyelitis, etc). Regarding metastases, the most frequent are breast, lung and prostate. ${ }^{2}$ Moreover, skeletal metastases in lung cancer can be present in up to $36 \%$ of patients, with the spinal cord being the most common location. ${ }^{3}$ This emphasises that lung cancer is often diagnosed in an advanced stage. Skull metastases, however, are uncommon even in advanced stages of tumours, although some cases have reported of temporal, ${ }^{45}$ calvarian $^{67}$ or frontal ${ }^{8}$ metastases as the initial manifestation of lung cancer. These metastases are usually lytic and pain is the main manifestation, which decreases patients' quality of life. That is why

\section{Learning points}

- Malignant lung tumours may be diagnosed at advanced stages, due to minimal symptoms of the disease.

- Spinal cord and axial metastases are common in the natural history of some types of cancer, such as lung tumours.

- Pain and the improvement in functionality and in quality of life are the main goals of therapy for lung cancer in an advanced stage with metastatic disease, that is, the treatment is for palliative rather than curative purposes. Notwithstanding, clinicians should be aware of the poor prognosis of these patients. therapy is often focused on reducing the pain and improving functionality, but this management is often palliative, not curative. Pain, neurological involvement and instability of lesions are the main indications for radiotherapy, as was the case for our patient.

Twitter Rafael García Carretero @my_phd_life

Contributors RGC wrote the first draft. MO-G and SH-P reviewed the manuscript and provided important contributions. PA-B was the radiologist who rendered the skull images in 3D.

Funding The authors have not declared a specific grant for this research from any funding agency in the public, commercial or not-for-profit sectors.

Competing interests None declared.

Patient consent for publication Consent obtained from next of kin.

Provenance and peer review Not commissioned; externally peer reviewed.

Case reports provide a valuable learning resource for the scientific community and can indicate areas of interest for future research. They should not be used in isolation to guide treatment choices or public health policy.

\section{ORCID iD}

Rafael García Carretero http://orcid.org/0000-0001-7532-4585

\section{REFERENCES}

1 Coleman RE. Clinical features of metastatic bone disease and risk of skeletal morbidity. Clin Cancer Res 2006;12:6243s-9.

2 Mundy GR. Metastasis to bone: causes, consequences and therapeutic opportunities. Nat Rev Cancer 2002;2:584-93.

3 Mitsuya K, Nakasu Y, Horiguchi S, et al. Metastatic skull tumors: MRI features and a new conventional classification. J Neurooncol 2011;104:239-45.

4 Cheng C-J, Yao N-S. Isolated temporal bone metastasis in a patient with non-small cell lung cancer. Eur J Radiol Extra 2005;55:75-7.

5 Bakhos D, Chenebaux M, Lescanne E, et al. Two cases of temporal bone metastases as presenting sign of lung cancer. Eur Ann Otorhinolaryngol Head Neck Dis 2012:129:54-7.

6 Isaka T, Maruno M, Suzuki T, et al. Skull metastases from atypical pulmonary carcinoid tumor in a 19-year-old Man-Case Report-. Neurol Med Chir 2006;46:609-13.

7 Jindal T, Sinha RK, Mukherjee S, et al. Calvarial and cutaneous metastasis as the primary presentation of a renal cell carcinoma. BMJ Case Rep 2014;2014. doi:10.1136/ bcr-2013-202830. [Epub ahead of print: 19 May 2014].

8 García Carretero R, Sanchez-Redondo J, Barrio-Alonso M-J, et al. Lung carcinoma presenting as a solitary, painless frontal bone lump. BMJ Case Rep 2015;2015. doi:10.1136/bcr-2015-212038. [Epub ahead of print: 16 Dec 2015].

Copyright 2022 BMJ Publishing Group. All rights reserved. For permission to reuse any of this content visit

https://www.bmj.com/company/products-services/rights-and-licensing/permissions/

BMJ Case Report Fellows may re-use this article for personal use and teaching without any further permission.

Become a Fellow of BMJ Case Reports today and you can:

- Submit as many cases as you like

- Enjoy fast sympathetic peer review and rapid publication of accepted articles

- Access all the published articles

- Re-use any of the published material for personal use and teaching without further permission

Customer Service

If you have any further queries about your subscription, please contact our customer services team on +44 (0) 2071111105 or via email at support@bmj.com.

Visit casereports.bmj.com for more articles like this and to become a Fellow 